\title{
JM
}

Volume 5 No. 1 (Juli 2017)

(C) The Author(s)

\section{HUBUNGAN PENDIDIKAN, TEMPAT TINGGAL, PENGETAHUAN SEKSUALITAS, DAN SITUS PORNOGRAFI DENGAN PERILAKU SEKSUAL PADA REMAJA PENGGUNA INTERNET DI RW 04 CIPETE UTARA, JAKARTA SELATAN}

\author{
RELATIONSHIPS OF EDUCATION, LIVING PLACES, SEXUALITY OF \\ KNOWLEDGE, AND PORNOGRAPHY SITES WITH SEXUAL \\ BEHAVIOR IN ADOLESCENT OF INTERNET USERS IN \\ RW 04 NORTH CIPETE SOUTH JAKARTA
}

\author{
DIYAH TEPI RAHMAWATI \\ AKADEMI KEBIDANAN DEHASEN BENGKULU
}

\begin{abstract}
ABSTRAK
Perilaku seksual meliputi segala tindakan yang dapat di amati secara empiris. Perilaku ini bisa berupa tindakan seseorang terhadap orang lain atau dirinya sendiri, mengungkapkan diri secara seksual, cara bicara dan cara bertindak (YPKP,2006). Tujuan penelitian ini adalah mengetahui faktor-faktor yang berhubungan dengan perilaku seksual pada remaja pengguna internet di RW 04 Kelurahan Cipete Jakarta Selatan Tahun 2009. Desain penelitian ini adalah cross sectional. Penelitian ini menggunakan data primer yang diambil dari responden yaitu pada remaja pengguna internet di RW 04 Cipete Utara Jakarta Selatan sebanyak 80 orang. Analisis yang digunakan adalah analisis univariat dan bivariat dengan pengolahan data menggunakan perangkat lunak komputer, hasil disajikan dalam bentuk tabel dan narasi. Hasil penelitian ini menemukan adanya hubungan yang bermakna antara pendidikan dan situs-situs pornografi dengan perilaku seksual remaja pada pengguna internet sedangkan faktor tempat tinggal dan pengetahuan tidak memperlihatkan adanya hubungan yang bermakna. Hasil uji statistik menunjukkan $\mathrm{p}$ value 0,000 dengan nilai OR 16,433 untuk faktor pendidikan dan hasil uji statistik untuk tempat tinggal menunjukkan $\mathrm{p}$ value 0,218 dengan nilai OR 2,400, sedangkan untuk pengetahuan seksualitas menunjukkan p value 0,541 dengan nilai OR sebanyak 0,684 , untuk situs pornografi menunjukkan $\mathrm{p}$ value 0,003 dengan nilai OR sebanyak 4,739. Dari hasil penelitian dapat disimpulkan bahwa pada umumnya perilaku seksual remaja pengguna internet RW 04 Cipete Utara Jakarta Selatan dalam kategori ringan/baik (57,5\%). Faktor pendidikan dan keterpaparan pornografi pada remaja berpengaruh dengan perilaku seksual pada remaja pengguna internet.
\end{abstract}

Kata kunci : internet, perilaku seksual, remaja

\begin{abstract}
Sexual behavior includes all actions that can be observed empirically. This behavior may be the act of a person against another person or his or her own self, expressing sexually, how to talk and how to act (YPKP, 2006). The purpose of this study is to determine factors related to sexual behavior in adolescent internet users in RW 04 Cipete Urban Village, South Jakarta Year 2009. The design of this study is cross sectional. This study uses primary data taken from respondents that is on teenage internet users in RW 04 Cipete Utara South Jakarta as many as 80 people. The
\end{abstract}


analysis used is univariate and bivariate analysis with data processing using computer software, result presented in table and narration. The results of this study found a significant relationship between education and pornography site sites with teenage sexual behavior on internet users while the factor of residence and knowledge does not show a meaningful relationship. The result of statistical test showed that $p$ value 0,000 with OR value of 16,433 for educational factor and statistical test for residence showed $\mathrm{p}$ value 0,218 with OR 2,400 value, while for sexuality knowledge showed $p$ value 0,541 with OR value 0,684 for site pornography shows $p$ value 0,003 with OR value 4,739. From the research results can be concluded that generally teenage sexual behavior internet users RW 04 North Cipete South Jakarta in the category of light / good (57.5\%). Factors of education and exposure of pornography in adolescents affect the sexual behavior of teens Internet users.

\section{Keywords: internet, sexual behavior, adolescent}

\section{PENDAHULUAN}

Masalah seks pada remaja seringkali mencemaskan para orang tua, juga pendidik, pejabat pemerintah, para ahli dan sebagainya. Di era globalisasi seperti ini banyak sekali pengekploitasian terhadap segala sesuatu yaitu ilmu pengetahuan sampai hal-hal yang bersifat pornografi, yang bisa membahayakan mental generasi muda Indonesia. Di dalam keadaan ini remaja sangat rawan terhadap apapun, mereka selalu ingin mencoba segala sesuatu yang ada di dunia ini tanpa memikirkan akibatnya di masa yang akan datang.

Menurut WHO batasan usia remaja adalah 10-24 tahun. Ada sekitar 60.861 .350 remaja berusia 10-24 tahun, atau sekitar $30,2 \%$ dari total penduduk Indonesia (YPKP, 2006). Berdasarkan profil kesehatan Indonesia tahun 2008 diketahui bahwa jumlah penduduk yang tergolong remaja usia 10-14 tahun sebesar $21.781 .000(10,7 \%)$ dan usia 15-19 tahun sebanyak $22.836 .100 \quad(11,2 \%)$ dari seluruh total penduduk Indonesia yang juga merupakan kelompok umur terbesar dibandingkan dengan golongan usia penduduk lainnya. ( BPS, 2008 ).

Keingintahuan remaja tentang perubahan-perubahan fisik yang sedang dialami serta organ-organ reproduksi yang mulai aktif seringkali tidak diimbangi dengan informasi yang benar mengenai hal ini. Kebanyakan remaja mendapatkan pendidikan mengenai apa yang terjadi pada tubuhnya dan bagaimana menyikapinya perubahan ini, sebagian besar orang tua maupun guru masih menganggap persoalan ini sebagai hal yang tabu untuk didiskusikan, akhirnya sebagian remaja merasa lebih nyaman mencari jawaban-jawaban atas keingintahuan mereka dari sumber-sumber yang dapat dengan mudah mereka akses. Sumber informasi yang mudah mereka jangkau adalah teman-teman sebaya ( peer group ), bacaan-bacaan popular, VCD porno, akses internet, dan lain-lain. Sumber-sumber informasi itu tidak selalu benar, terbaik dan bermutu. (Mahfiana, dkk. 2009 ).

Gambaran tentang perilaku seks yang beresiko tinggi terjadi di Indonesia sebagaimana dipaparkan oleh Made Putri Ayu Rasmini (2008) berikut ini. Pada bulan April 2007 SMA Negeri 2 Denpasar bekerjasama dengan Kelompok Siswa Peduli AIDS dan Narkoba (KSPAN) SMA Negeri 2 Denpasar dan Fakultas Kedokteran Universitas Udayana, Bali, mengadakan penelitian tentang perilaku seks remaja sekolah di Denpasar. Dari responden yang jumlahnya $766,68,6 \%$ responden hanya berpelukan, $59,8 \%$ melakukan cium kering, $26,4 \%$ berani mencium leher ( necking ), 18\% responden sudah menggesek-gesekkan alat kelamin tanpa berhubungan seks (petting), 13,4\% responden sudah pernah hubungan seksual, dan 20,8\% menyatakan aktivitas seksual lain selain yang disebutkan tadi. Aktivitas seksual tersebut bisa dilakukan bersama teman, pacar, seseorang atau beberapa orang tanpa status yang jelas, bahkan dengan pekerja seks komersil (PSK). Dalam penelitian tersebut 
ditemukan fakta bahwa dari 766 responden ternyata $13,4 \%$ orang pernah melakukan hubungan seksual dan bahkan $6,4 \%$ orang di antaranya melakukan hubungan seksual dengan PSK ( Rasmini, 2007 ).

Pakar seks spesialis Obstetri dan Ginekologi di Jakarta mengungkapkan, dari tahun ke tahun data remaja yang melakukan hubungan seks bebas semakin meningkat. Dari sekitar lima persen pada tahun 1980-an, menjadi dua puluh persen pada tahun 2000 (Nugraha,2006).

Para ahli berpendapat kemajuan teknologi khususnya teknologi informasi seperti pedang bermata dua. Satu sisi membawa banyak kemudahan dan manfaat baru akan tetapi disaat yang sama membawa pengaruh buruk yang tidak kalah mengkhawatirkan. Salah satu dampak negatif dari kemajuan teknologi informasi tersebut adalah pornografi di internet cyberporn dan berseks maya cybersex. Situs-situs porno di Internet yang dapat diakses oleh siapapun berdasarkan laporan American Demographic Magazine, disebutkan bahwa jumlah situs porno meningkat pesat dari 22.100 pada 1997 menjadi 280.300 pada tahun 2000. Data ini setidaknya dalam kurun waktu tiga tahun terakhir, telah melonjak 10 kali lipat. Faktanya, di Indonesia media internet adalah sumber materi pornografi yang tidak hanya mudah diakses, tetapi juga mudah diproduksi. Kantor berita Associated Press pada tahun 2004 menyebutkan Indonesia sebagai “ The next heaven of Pornography" setelah Rusia dan Swedia( Soebagijo, 2008 ).

Pakar telematika Roy Suryo menyebut satu angka fantastis mengenai jumlah situs porno buatan asli orang Indonesia. Dari sekitar 24,5 juta situs dengan admin (pengelola) orang Indonesia, lebih dari satu jutanya adalah situs porno. Hal itu diungkapkan Roy yang ditemui usai Konferensi Pers Pengesahan UU Informasi dan Transaksi Elektronik (ITE) di Hotel Sultan, Jakarta, Selasa ( KOMPAS, 25/3/08).

Media pornografis saat ini telah berkembang menjadi referensi pengetahuan dan pemahaman anak-anak dan remaja tentang realitas kehidupan seksual. Pesanpesan permestif seksual, seperti gaya hidup seks bebas, yang banyak terdapat di media internet perlahan membentuk remaja dan anak-anak menjadi pribadi yang terobsesi secara seksual. Pornografi kini tersedia telah beragam dan dapat dijangkau dengan sangat mudah bahkan murah oleh siapapun termasuk remaja. Data Yayasan Buah Hati pada tahun 2005 menunjukkan dari 1705 murid SD kelas 4 sampai dengan kelas 6 di Jabodetabek, 25 $\%$ telah mengakses dan mengkonsumsi media pornografi melaui HP, $20 \%$ melalui internet, dan sisanya melalui media lainnya. Survei Lembaga pemerhati internet "Jejak Kaki Internet Protection di DKI Jakarta ( Majalah Kartini 27 April-11 Mei 2006) menunjukkan $27 \%$ remaja pernah membuka situs porno, $97 \%$ remaja mengetahui mereka bisa mendapatkan situs berbau pornografi di Internet, 67\% remaja akan membuka situs porno jika ada kesempatan (Soebagijo, 2008).

RW 04 berada di Kelurahan Cipete Utara Jakarta Selatan dimana wilayah tersebut merupakan lokasi yang strategis menuju perkantoran, pusat perbelanjaan yang terdapat di sekitar wilayah Jakarta Selatan.Tak jauh dari lokasi tersebut terdapat Kampus atau Sekolah tinggi sehingga banyak karyawan serta mahasiswa yang mondok atau kost di sekitar wilayah Rw 04 Kelurahan Cipete Utara tersebut.Warga memanfaatkan kondisi ini untuk membuka usaha yang ada kaitannya dengan keperluan atau kebutuhan para penggunanya seperti tempat kost, tempat fotokopi, wartel, rental dan beberapa warnet. Tujuan penelitian ini adalah mengetahui faktor-faktor yang berhubungan dengan perilaku seksual pada remaja pengguna internet di RW 04 Kelurahan Cipete Jakarta Selatan Tahun 2009.

\section{METODE PENELITIAN}

Jenis penelitian adalah kuantitatif dan menggunakan metode deskritif analitik dengan pendekatan cross sectional dimana pengukuran variabel dependen serta variabel independen diambil secara bersamaan ketika 
penelitian dilaksanakan, dan uji pada penelitian ini yaitu analisa bivariat dengan uji chi square.

Penelitian ini dilakukan di warung internet RW 04 Kelurahan Cipete Utara Jakarta Selatan pada pertengahan bulan Desember 2009. Populasi dalam penelitian ini adalah seluruh remaja laki-laki dan perempuan pengguna internet yang berusia 10-24 Tahun. Pengunjung warnet di RW 04 Kelurahan Cipete Utara Jakarta Selatan selama dua minggu pada bulan Desember sebanyak 80 remaja. Pengambilan sampel didasarkan pada kriteria inklusi yaitu pengunjung yang berbeda di warnet Rw 04 Cipete Utara Jakarta Selatan. Sampel yang diambil adalah keseluruhan total populasi.

Perhitungan besar sampel berdasarkan rumus yang sesuai dengan disain kros seksional dengan rumus pengujian hipotesis untuk dua proporsi (Lemeshow, 1997) sebagai berikut:

$$
\begin{aligned}
& \left\{\mathrm{Z}_{(1-\mathrm{a} / 2)} \ddot{\mathrm{O}}[2 \mathrm{P}(1-\mathrm{P})]+\mathrm{Z}_{(1-\mathrm{b})} \mathrm{O}[(\mathrm{P} 1(1-\mathrm{P} 1)+\right. \\
& \mathrm{P} 2(1-\mathrm{P} 2)]\}^{2}
\end{aligned}
$$

$$
(\mathrm{P} 1-\mathrm{P} 2)^{2}
$$

\section{HASIL PENELITIAN}

Penelitian dilakukan disalah satu warung internet yang berada di RW 04, dimana merupakan bagian dan terletak di Kelurahan Cipete Utara Kecamatan Kebayoran Baru Kotamadya Jakarta Selatan Tahun 2009.

Adapun kondisi umum yang terdapat di RW 04 antara lain :

\begin{tabular}{cc}
\hline Luas Wilayah & $1.624,9 \mathrm{M}^{2}$ \\
\hline Penduduk & $1.772 \mathrm{Jiwa}$ \\
\hline Jumlah KK & $352 \mathrm{KK}$ \\
\hline Jumlah RT & $10 \mathrm{RT}$ \\
\hline
\end{tabular}

Batas wilayah, antara lain :

\begin{tabular}{cc}
\hline Utara & Jl. Prapanca Raya \\
\hline Timur & Jl. Damai V ( RW 08 ) \\
\hline Selatan & Jl. Damai Raya ( RW 02 ) \\
\hline Barat & Kali Asem ( RW 01 ) \\
\hline
\end{tabular}

Perilaku seksual dapat dilihat ketika seseorang berpacaran. Ketika berpacaran orang sering melakukan berbagai hal, baik untuk menunjukkkan kasih sayang ataupun untuk coba-coba.Pada penelitian ini untuk melihat perilaku seksual responden ditanya apakah ketika pacaran pernah berpasangan atau bergandengan tangan, berciuman, meraba daerah kelamin pacar sampai dengan berhubungan seksual.

\section{Tabel 1. Distribusi perilaku seksual pada remaja pengguna internet}

\begin{tabular}{ccc}
\hline Perilaku Seksual & Jumlah & Presentase ( \%) \\
\hline $\begin{array}{c}\text { Berpegangan } \\
\text { Tangan }\end{array}$ & 46 & 57,5 \\
\hline Berciuman Bibir & 30 & 37,5 \\
\hline $\begin{array}{c}\text { Menyentuh Bagian } \\
\text { Sensitif }\end{array}$ & 2 & 2,5 \\
\hline $\begin{array}{c}\text { Berhubungan } \\
\text { Kelamin }\end{array}$ & 2 & 2,5 \\
\hline
\end{tabular}

Pada tabel 1 diketahui bahwa kegiatan yang paling banyak dilakukan responden dengan pacarnya pada saat berpacaran adalah berpegangan tangan (57,5\%), berciuman $(37,5 \%)$. Hanya sedikit responden ketika berpacaran meraba daerah kelamin pacar $(2,5$ $\%$ ) atau melakukan hubungan seksual $(2,5$ $\%$ ).

Untuk mendapatkan gambaran perilaku seksual pada remaja pengguna internet maka kegiatan responden pada saat berpacaran dibagi menjadi dua kelompok, yaitu perilaku seksual berat dan ringan.Perilaku seksual responden dikatakan berat apabila ketika/saat berpacaran pernah berciuman, meraba alat kelamin sampai dengan berhubungan seksual. Dan dikatakan beresiko rendah apabila responden hanya ngobrol, nonton film serta jalan - jalan berdua dan hanya sampai dengan berpegangan tangan. 
Tabel 2. Hasil analisis univariat sebaran Responden mengenai perilaku seksual remaja pengguna internet di RW 04 Cipete Utara Jakarta Selatan Periode Desember $2009(n=80)$

\begin{tabular}{ccc}
\hline & \multicolumn{2}{c}{ Frekuensi } \\
\cline { 2 - 3 } Variabel & Jumlah & $\begin{array}{c}\text { Presentase } \\
(\mathbf{\%})\end{array}$ \\
\hline $\begin{array}{c}\text { Perilaku Seksual Remaja } \\
\text { - Perilaku Seksual Berat }\end{array}$ & 34 & 42,5 \\
- Perilaku Seksual Ringan & 46 & 57,5 \\
\hline$\quad$ Pendidikan & & \\
- Tidak Tinggi & 41 & 51,3 \\
$\quad$ - Tinggi & 39 & 48,8 \\
\hline Tempat Tinggal & & \\
- Tanpa Orang Tua & 15 & 18,8 \\
- Dengan Orang Tua & 65 & 81,2 \\
\hline Pengetahuan Seksualitas & & \\
$\quad$ - Kurang & 42 & 52,5 \\
$\quad$ - Baik & 38 & 47,5 \\
\hline Situs Pornografi & & \\
$\quad$ Pernah & 42 & 52,5 \\
Tidak Pernah & 38 & 47,5 \\
\hline
\end{tabular}

Dari tabel diatas dapat dilihat distribusi frekuensi adalah sebagai berikut:

Remaja pengguna internet yang melakukan perilaku seksual berat sebanyak 34 orang $(42,5 \%)$. Pendidikan remaja saat dilakukan penelitian sebagian besar berpendidikan tidak tinggi sebanyak 41 orang $(51,3 \%)$, bertempat tinggal sebagian besar dengan orang tua sebanyak 65 orang ( $81,2 \%)$, yang berpengetahuan kurang sebanyak 42 orang $(52,5 \%)$ dan yang pernah membuka situs pornografi sebanyak 42 orang $(52,5 \%)$.

Tabel 3. Hasil analisis bivariat hubungan pendidikan, tempat tinggal, pengetahuan seksualitas dan situs pornografi dengan perilaku seksual pada remaja pengguna internet di RW 04 Cipete Utara Jakarta Selatan

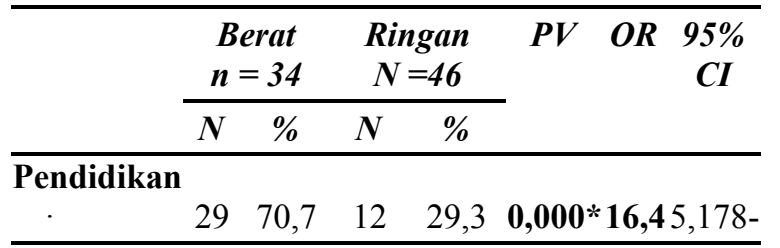

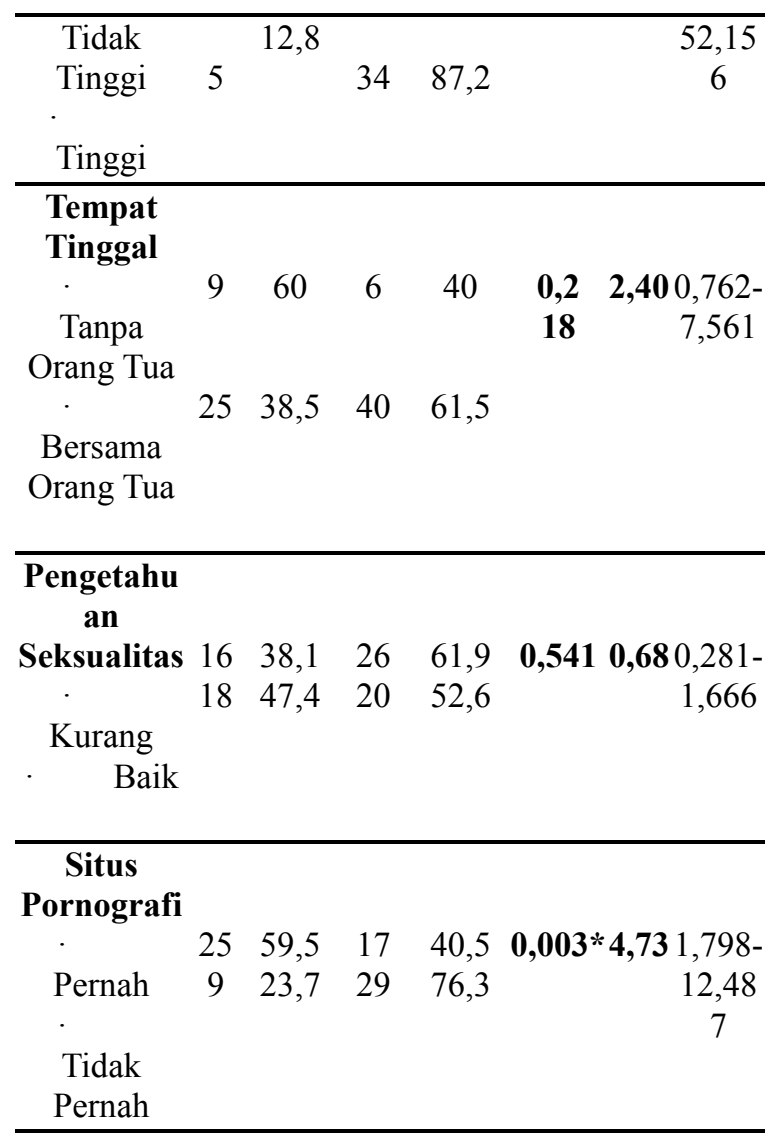

\section{PEMBAHASAN}

Hubungan pendidikan dengan perilaku seksual pada remaja pengguna internet.

Pada tabel diatas dapat dilihat dari hasil perhitungan statistik diperoleh $\mathrm{p}$ value $=$ $0,000<\alpha 0,05$, sehingga dapat disimpulkan terdapat hubungan bermakna dan Ha diterima ( 95\% CI : 5,178-52,156 ). Dan untuk nilai OR diperoleh sebesar 16,433 dan dapat diintrepetasikan bahwa remaja pengguna internet yang berpendidikan tidak tinggi mempunyai resiko lebih besar melakukan perilaku seksual remaja dibandingkan dengan remaja pengguna internet yang berpendidikan tinggi.

Hal ini sejalan dengan teori dimana pendidikan adalah upaya persuasif atau pembelajaran pada masyarakat mau melakukan tindakan-tindakan untuk memelihara atau mengatasi masalah dan meningkatnya kesehatannya yang dihasilkan oleh pendidikan kesehatan ini berdasarkan kepada pengetahuan, kesadaran dan 
pembelajaran ( Notoadmojo, 2003 ).

Selain itu pendidikan normatif, budi pekerti dan agama memang sangat perlu buat bisa mencegah berbuat yang bertentangan dengan norma umum. Tetapi jauh lebih strategis juga adalah pentingnya pendidikan seks itu sendiri. Supaya remaja punya pemahaman akan risiko tindakan yang dilakukan dan membawa remaja menjadi remaja bertanggung jawab dan ini tugas kita bersama. Paling tidak dalam kasus ini remaja jadi menunda hubungan seks atau pacaran sehat tapi buat yang terlanjur gonta-ganti mereka bisa melindungi dirinya dari kehamilan tidak diinginkan, infeksi menular seksual, dan HIV/AIDS (Rasmini, 2007). Dengan kata lain pendidikan seks pada setiap tingkatan pendidikan sangatlah penting dan harus diberikan kepada semua remaja.

\section{Hubungan tempat tinggal dengan perilaku seksual pada remaja pengguna internet.}

Pada tabel diatas dapat dilihat dari hasil perhitungan statistik diperoleh $p$ value 0,218 $>\alpha 0,05$ sehingga dapat disimpulkan tidak terdapat hubungan bermakna dan Ha ditolak ( 95\% CI : 0, $762-7,561$ ), Akan tetapi untuk nilai OR yang diperoleh sebesar 2,400 dapat diintrepetasikan bahwa remaja pengguna internet yang tinggal tanpa orang tua mempunyai kecenderungan beresiko 2,400 lebih besar untuk melakukan perilaku seksual remaja dibandingkan dengan remaja pengguna internet yang tinggal dengan orang tua.

Sedangkan pada hasil penelitian Taufik (2005) di Surakarta kebanyakan alasan remaja melakukan hubungan seksual karena adanya pengaruh lingkungan agar tidak ketinggalan zaman dan dianggap gaul $(6,94 \%)$, serta menurut hasil penelitian (Marthalena, 2008) dengan rancangan cross sectional ditemukan $79 \%$ responden remaja yang tidak tinggal dengan orang tua berpeluang melakukan perilaku seksual remaja beresiko ( $\mathrm{OR}=0,19$ dan $\mathrm{x}^{2}$ hitung $=8,211$ ). Hal ini tidak sejalan dengan hasil penelitian diatas dikarenakan adanya perbedaan sampel, pada penelitian
Mahfiana sampel yang diteliti lebih banyak.

Menurut teori orang tua merupakan orang pertama yang memberikan dasar pembentukan tingkah laku, watak, moral, dan pendidikan kepada anak. Pengalaman interaksi dalam keluarga akan menentukan pola dan tingkah laku anak kepada orang lain. Orang tua ikut mempersiapkan anak memasuki masa remaja dan menjadi faktor penentu dalam menanamkan corak kepribadian seseorang sampai dewasa, (Mahfiana, 2009).

Hal ini juga tidak sejalan dengan teori lainnya dimana pengaruh dari luar atau lingkungan tempat tinggal remaja yang tidak baik akan menimbulkan hal-hal yang beresiko bagi remaja yang tidak mendapatkan pendidikan seks terutama dari orang tua atau keluarganya (Dianawati, 2003) karena tempat tinggal juga mempengaruhi tingkah laku individu setiap hari mulai konsepsi sampai akhir hayatnya, dan sangat menentukan tercapainya atau tidak potensi bawaan, sedangkan yang kurang baik akan menghambatnya.

Pada masa perkembangan remaja yang semakin meningkat terhadap tuntutan seksualitas ditambah kecenderungan remaja memiliki rasa ingin tahu yang tinggi terhadap sesuatu, makin mendorong remaja untuk melakukan berbagai hal dalam memenuhi rasa ingin tahu tersebut. Dimulai dari pencarian informasi yang dibutuhkan sampai kearah tindakan mencoba. Untuk itu peranan pendamping khususnya orang tua dan kewaspadaan sangat diperlukan.

\section{Hubungan pengetahuan seksualitas dengan perilaku seksual pada remaja pengguna internet.}

Pengetahuan merupakan hasil dari tahu, dan ini terjadi setelah orang melakukan penginderaan terhadap suatu obyek tertentu (Notoadmodjo, 2007 ). Pada tabel diatas dapat dilihat dari hasil perhitungan statistik diperoleh $\mathrm{p}$ value $=0,541>\alpha 0,05$ sehingga dapat disimpulkan tidak terdapat hubungan bermakna dan Ha ditolak ( 95\% CI : 0,281 - 
1,666 ). Dan untuk nilai OR yang diperoleh sebesar OR 0,684 dapat diintrepetasikan bahwa pengetahuan remaja pengguna internet tidak ada hubungan dengan perilaku seksual remaja.Hal ini pun tidak sejalan dengan teori diatas, Teori lain menyebutkan remaja kurang pengetahuan dasar tentang anatomi dan fisiologi reproduksi, bagaimana terjadinya hamil dan seterusnya, bagaimana mencegahnya dan dimana mendapatkan perlindungan. Orang tua yang merasa aman, malu, menceritakan tentang seks dengan anak-anaknya. Walaupun remaja telah mempunyai kematangan kognitif namun dalam kenyataannya mereka belum mampu mengolah informasi yang diterima dengan benar. Akibatnya perilaku seksual remaja sering tidak terkontrol dengan baik. Selain itu rasa ingin tahu besar untuk mencoba segala hal yang belum diketahui sangat mempengaruhi remaja melakukan perilaku seksual aktif yang beresiko, karena pada umumnya remaja ingin mengetahui banyak hal yang hanya dapat dipuaskan serta diwujudkannya melalui pengalaman mereka sendiri (Learning by Doing).( YPKP, 2006). Sehingga demikian teori ini pun bertentangan dengan hasil penelitian diatas.

Akan tetapi disisi lain responden remaja RW 04 sebagian besar berpendidikan tinggi akan tetapi berpengetahuan kurang, hal ini dapat dipengaruhi karena sebagian besar orang tua atau masyarakat disana masih menganggap persoalan perilaku seksual sebagai hal yang tabu untuk di diskusikan.

Menurut penelitian, 47,4\% remaja yang berpengetahuan kurang berpeluang melakukan perilaku seksual $(\mathrm{OR}=0,356)$ dan menunjukkan hubungan bermakna dengan perilaku seksual remaja ( $p$ value 0,000), (Kushendiati, 2009 ). Sehingga dapat terlihat bahwa hubungan yang tidak bermakna dari hasil penelitian ini dikarenakan sampel yang diambil dalam penelitian ini terbatas berbeda dengan penelitian Kushendiati yang menggunakan sampel hingga ribuan responden, rancangan penelitian nya berupa studi analitik dengan menggunakan data sekunder dan instrumen penelitiannya berupa kuesioner yang diambil dari Survei Perilaku Beresiko yang Berdampak pada Kesehatan Reproduksi Remaja Tahun 2002 yang telah dilaksanakan LD-FEUI bekerjasama dengan BKKBN dan UNFPA.

\section{Hubungan situs pornografi dengan perilaku seksual pada remaja pengguna internet.}

Pada tabel diatas dapat dilihat dari hasil perhitungan statistik diperoleh $\mathrm{p}$ value $=$ $0,003>\alpha 0,05$, sehingga dapat disimpulkan terdapat hubungan bermakna dan Ha diterima ( $95 \%$ CI : 1,798 - 12,487 ). Dan untuk nilai OR diperoleh sebesar 4,739 dan dapat diintrepetasikan bahwa pada remaja pengguna internet yang pernah membuka situs pornografi mempunyai kecenderungan resiko 4, 739 lebih besar untuk melakukan perilaku seksual remaja dibandingkan dengan yang tidak.

Hasil penelitian yang telah dilakukan (Kushendiati, 2005) menunjukkan pula terdapat hubungan bermakna antara remaja yang terpapar pornografi dengan perilaku seksual remaja, yaitu sebesar 11,8\% beresiko tinggi untuk melakukan perilaku seksual remaja. Situs-situs tersebut sangat berpengaruh buruk terhadap perilaku seharihari.Pengaksesan situs-situs berbau pornografi secara terus menerus dapat mengakibatkan degradasi moral para penggunanya, khususnya remaja yang sering mengaksesnya.Pornografi (dampak teknologi), dapat terjadi bila orang tua tidak mengontrol surfing internet, tontonan dan bacaan anak. Salah bergaul, dapat terjadi bila orang tua tidak mengontrol frekuensi anak keluar rumah termasuk dalam memilih teman bergaulnya ( Soebagidjo, 2008 ).

Seperti yang diungkapkan oleh Richard Kartawijaya dari sekitar 1,8 Juta warga Indonesia yang sudah mengenal dan mengakses internet diantaranya ternyata tidak bisa menahan diri untuk tidak membuka situs porno ( Papu, 2001 )

Sehingga antara hasil penelitian diatas dan teori yang ada menunjukkan hubungan 
yang saling berkaitan. Dengan kata lain Pornografi (dampak teknologi), dapat terjadi bila orang tua tidak mengontrol surfing internet, tontonan dan bacaan anak. Salah bergaul, dapat terjadi bila orang tua tidak mengontrol frekuensi anak keluar rumah termasuk dalam memilih teman bergaulnya ( Soebagidjo, 2008 ).

Bila remaja terus menerus mengkonsumsi pornografi, sangat mungkin ia akan terdorong untuk melakukan hubungan seks pada usia terlalu dini, dan di luar ikatan pernikahan. Apalagi pornografi umumnya tidak mengajarkan corak hubungan seks yang bertanggungjawab, sehingga potensial mendorong perilaku seks yang menghasilkan kehamilan remaja, kehamilan di luar nikah atau penyebaran penyakit yang menular melalui hubungan seks, seperti PMS/AIDS.

\section{KESIMPULAN}

Dari hasil penelitian diketahui bahwa di RW 04 Cipete Utara Kebayoran Baru Jakarta Selatan yaitu Proporsi remaja pengguna internet yang mempunyai perilaku seksual berat yaitu sebanyak 42,5\%; Pendidikan responden remaja pengguna internet dalam penelitian ini sebagian besar berpendidikan tidak tinggi sebanyak 41 orang $(51,3 \%)$; Situs Pornografi pada penelitian ini sebagian besar responden remaja pengguna internet yang pernah mengaksesnya sebanyak 42 orang (52,5\%); Dari hasil penelitian variabel pendidikan dan situs pornografi terdapat hubungan bermakna. Diharapkan masyarakat dapat memperkaya informasi dan mengetahui seberapa jauh pengaruh internet dan mediamedia lain terhadap perilaku seks remaja / para penggunanya serta perlunya dibentuk Bina Keluarga Remaja (BKR).

\section{DAFTAR PUSTAKA}

Agustina, Santi. 2004. Faktor-Faktor Yang Berhubungan Dengan Perilaku Seksual Remaja di Panti Sosial Bina Remaja 'Taruna Jaya' Tebet Jakarta Selatan.

Ambarwati, Katharina, dkk. 2003.Internet dan Perilaku Seksual Remaja, Bagian Pendidikan Kesehatan dan Perilaku FKM Univ Airlangga, Surabaya. 2005. The Indonesian of Journal of Public Health, Vol 2, No 1, Juli : 10 - 16

Anninda Online, 2005.Kecanduan Internet (2), Ed. www.ummigroup.co.id

BPS ( Badan Pusat Statistik ), 2008.Survey Total Penduduk Indonesia ( Jakarta Dalam Angka 2008 ).

Dianawati, Ajen, 2003.Pendididkan Seks untuk Rema. Jakarta : Kawan Pustaka

Fatimah, dkk. 2009.Membuat Usulan Proposal KTI dan Laporan Hasil KTI. Jakarta : C. V. Trans Info Media.

Green, Lawrence w. Et al, 1980.Health Education Planning : A diagnostik Approach. California Mayfield Published Company.

Hidayat, Mulyadi. dkk. 2003.Premartial Sexsual Behavior among Adolescence In Jakarta. Maj Kedokt. Atma Jaya, Vol 2. No.1 : 75-83.

Huriah, Titih, dkk. 2007.Pengaruh Pendidikan Kesehatan Reproduksi oleh Kelompok Sebaya ( Peer Group) terhadap Pengetahuan Kesehatan reproduksi Remaja di SMP Negri 2 Kasihan Bantul, Yogyakarta.Mutiara Medika. 2008.Jurnal Kedokteran dan Kesehatan volume 8, nomor 2.Juli.

Kamus Besar Bahasa Indonesia.Edisi ketiga, Balai Pustaka, Jakarta, hlm 889.

Kompas, 25 Maret 2008.Konfrensi Pers Pengesahan UU Informasi dan Transaksi Elektronik( ITE), Di Hotel Sultan, Jakarta.

Kushendiati, Meila. 2005.Hubungan Karakteristik Remaja, Pornografi Dan Sumber Informasi Dengan Perilaku Seksual Remaja Di Empat Provinsi Di Indonesia.

Lameshow, Stanley et al, 1997. Besar Sampel Dalam Penelitian Kesehatan. Yogyakarta : Gadjah Mada University Press Indonesia.

Mahfiana, Layyin dkk. 2009.Remaja dan Kesehatan Reproduksi. Ponorogo :STAIN Ponorogo Press 
bekerjasama dengan Centre for Religion and Sexuality.

Marthalena, Happy.2008Faktor- Faktor Yang Berhubungan Dengan Perilaku Seksual Remaja Pada Mahasiswa Diploma III Kebidanan Politeknik Karya Husada Jakarta.

Martopo, Didik I. 2002.Tren Perilaku Remaja di Era Millenium.www.bkkbn.go.id.

Notoadmodjo, Soekidjo. et al. 2002. Metodologi Penelitian Kesehatan, Penerbit P. T Rineka Cipta, Jakarta.

2003.

Pengantar Pendididkan Kesehatan dan Ilmu Perilaku, Cetakan pertama. Yogyakarta : Andi Offset

2007.

Promosi Kesehatan teori dan Aplikasi ( Ilmu Perilaku). Jakarta : P.T Rineka Cipta.

Nugraha, Boyke Dian, 2006.Remaja Melakukan Hubungan Seks Meningkat. www.ceria.bkkbn.go.id

Oetomo, Budi Sutedjo Dharma. et al. 2001. Perspektif E-Business, Yogyakarta : C. V Andi Offset.

2003. Kamus ++ Jaringan Komputer, Yogyakarta:

C. V Andi Offset

2007. Pengantar Teknologi Informasi Internet, Yogyakarta :penerbit C. V Andi Offset

Papu, Johanes. 2001. Situs Porno dan Kesehatan Ment. www.e-psikologi.com.

Pinem, Saroha. 2009.Kesehatan Reproduksi dan Kontrasepsi.Jakarta : C. V Trans Info Media.

Port, Otis. 2004." Sang Penemu Jaringan Internet", Business Week, Edisi Indonesia,

No.18/III/13 Oktober 2004, Halaman 6.

Rasmini, Made Putri Ayu. 2007. Menguak Perilaku Seks Remaja. Denpasar, Harian Bali Kabar Anyar 18th July 2007.

Rahmawati, Diyah Tepi. 2009. Survey Pendahuluan, Perilaku Seksual pada Remaja Pengguna Internet di RW 04 Cipete Utara Jakarta Selatan.
Sarwono, Sarlito Wirawan, 2008.Psikologi Remaja. Jakarta : P.T Raja Grafindo Persada, Jakarta.

Soebagijo, Azimah. 2008.Pornografi Dilarang Tapi Dicari, Jakarta :Penerbit Gema Insani.

Wiknjosastro, Gulardi, dkk. 2006.Modul Mahasiswi Kesehatan Reproduksi. Penerbit Yayasan Pendidikan Kesehatan Perempuan ( YPKP ) bekerjasama dengan PusatTenagaKesehatan

( Pusdiknakes ) DepKes dan Ikatan Bidan Indonesia ( IBI ), Jakarta

(http :// ceria. bkkbn. go.id)

http://situs.kesrepro.info/krr/referensi2.htm http://situs.kesrepro.info/krr/referensi5.htm

(www.smallcrab.com/.../592-pornografi-dimedia-massa-dan-pengaruhnya-padaremaja).

http://id.Wikipedia.org /wiki/hubungan seksual/pornografi 